\title{
Perceptions of Parents of Children Admitted to the Emergency Room and of Doctors Regarding the Urgency of Situation and the Factors Affecting Perceptions
}

\author{
Orhan Gevrek', Oktay Sarı ${ }^{1}$, Ümit Aydoğan ${ }^{1}$, Halil Akbulut ${ }^{1}$, Kenan Sağlam², Okan Özcan ${ }^{3}$ \\ 'Department of Family Medicine, Gülhane Military Medical Faculty, Ankara, Turkey \\ 2Department of Internal Medicine, Gülhane Military Medical Faculty, Ankara, Turkey \\ ${ }^{3}$ Department of Pediatrics, Gülhane Military Medical Faculty, Ankara, Turkey
}

\begin{abstract}
Aim: In our study involving children who were presented to the emergency service, we investigated the parents' and physicians' perception of urgency.

Materials and Methods: The study was performed on physicians and on families of pediatric patients who were admitted to the Children's Emergency Department between April 2011 and 2012. Families and Physicians were asked to fill out a questionnaire about the emergency status of their children.

Results: A total of $61.1 \%$ of parents ( $n=1081$ ) who presented their children to the emergency service declared that their children must be seen by a physician in $15 \mathrm{~min}$. Of them, $56.2 \%(n=994)$ reported more than $12 \mathrm{~h}$ had passed since the complaints of their children started. Only $3.7 \%$ of parents ( $n=67)$ stated that they visited the emergency department because of a real emergency status. A total of $36.6 \%$ of parents $(n=647)$ mentioned that they preferred to visit the emergency service because they work during the day, and $40.6 \%$ of parents $(n=719)$ preferred to visit the emergency service because outpatient clinics are crowded during the day. Physicians reported that the examination of $64.2 \%$ of patients ( $n=1137)$ could be safely postponed to the next day.
\end{abstract}

Conclusion: The method to provide health services to those patients in real need in the emergency room is to raise awareness in the society. We believe that training courses given at primary healthcare services could reduce inappropriate visits to the emergency service. (Eurasian J Emerg Med 2015; 14: 183-8)

Keywords: Emergency service, parental perception, urgency of disease

\section{Introduction}

The purpose of the emergency services, regardless of patients' age, sex, application (or consult) type, and ability of pay, is to diagnose and treat their acute life-threatening illnesses. The emergency room (ER) ensures the coordination between other medical disciplines while preventing prior complications $(1,2)$. In this respect, the ERs constitute the strongest link between health services (3). When examining (or analyzing) the number of presentations to the $E R$, it has been seen that a large proportion of patients can be treated by health care providers in the outpatient setting as the first step (or primary care) (4).

Currently, presentation to the ER, except for the purpose, has reached substantial levels. The biggest reason of this is the perception of the community about the urgency of the diseases (3). In the study by Prince and Worth (5), it was reported that $35 \%$ of parents who brought their children to the ER misperceived the severity of their children's disease. In Turkey, approximately 15 million children are brought to the ER per year (6). According to the American Academy of Emergency Medicine's (ACEP) classification of urgency, only $20 \%$ of these if they do not have early and appropriate medical intervention can cause significant damage or death; these cases are called as "very urgent" patients (7).
Perception is a wholesale meaningful and systematic reaction of the organism against objects and events. Perceptions occur as a result of sensations (8). Particularly, parents tend to see their children's illnesses as a serious condition because of the frequency of illness (9). This situation makes parents aggressive, and their perceptions are affected negatively $(10,11)$. In our study, we compare the perceptions of the parents who brought their children to the ER and those of the doctors who examined these children; in addition, we researched the factors affecting the perception of urgency.

\section{Materials and Methods}

Our research was conducted with the participation of a total of 1834 parents who brought their children to the Pediatric ER in Gülhane Military Medical Academy in the determined days between the years 2011 and 2012 and included 18 pediatricians. Our study is a cross-sectional study. Permission had been obtained from the Ethics Committee of Gülhane Military Medical Academy before the start of the study. The questionnaire was improved by the researchers after reviewing the literature. Pre-implementation had been performed for 10 parents to evaluate their intelligibility. The purpose of the study had been described to the parents who

Correspondence to: Orhan Gevrek e-mail: orhan.gevrek@gmail.com

Received: 29.12.2014 Accepted: 21.04.2015

(C) Copyright 2015 by Emergency Physicians Association of Turkey - Available online at www.eajem.com DOI: 10.5152/eajem.2015.35682 
agreed to participate after making corrections, and the questionnaire was administered face-to-face. Also the pediatricians filled the questionnaire that had been prepared by the researchers in charge.

While determination of the universe of our study, it was decided to be done at a certain rate according to the frequency of the appeals to the ER. Because the visit to the ER varies from dateto-date and month-to-month. The questionnaire was not applied to all patients and not during all days. In the first week, the application date of the questionnaire was the first day of the week; in the second week, the day of application was the second day. That went on the route like this till the last of the study which had last seven weeks in every period in that year. The number of presentations to the ER in the year 2010 was evaluated, and the coefficient of each month was obtained after comparing and rationalizing of the months. The number of presentations in the days of January 2010 was evaluated, and the coefficient of each day was obtained after comparing and rationalizing of these days. According to these data, the daily number of patients was achieved by targeting $10 \%$ of the average number of presentations. Forty-nine of 4480 pediatric patients were brought to the ER in the determined 49 study days. The questionnaire was applied to the parents of 1834 child patients. Our sample group consist of 1770 parents who suited rules and filled the questionnaire completely. All 18 physicians working in the pediatric ER filled out the questionnaire.

Trauma patients' parents, parents who were not well educated and who could not fill out the questionnaire, chronic patients' parents, parents using anxiety drugs, and resuscitated patients' parents were not involved in our study so that our data could not be affected from patients' excessive anxiety.

Parents' sociodemographic characteristics, children's health condition before being brought to the ER, and the time of complaints about illness and interventions were asked in our questionnaire. In addition, the causes of parents visit to the ER were investigated. In our study, the urgencies of children were classified according to the criteria of "Centers for Disease Control and Prevention (CDC)" of the USA. They were grouped as follows: "Very Urgent," who need intervention before 15 min; "Urgent," who need intervention between 15 min and $60 \mathrm{~min}$; and "Semi-urgent," who need intervention between $1 \mathrm{~h}$ and $2 \mathrm{~h}(7)$.

\section{Statistical analysis}

The data was installed on the computer after collection and was evaluated by the Statistical Package for the Social Sciences 16.00 program (SPSS Inc. Chicago, IL, USA). For the analysis of the data, numbers, percentage, and mean as well as standard deviation values were used. For continuous variables and discrete variables, $t$ test and chi-square test were used, respectively, for comparison of the data. Backward likelihood ratio logistic regression analysis was conducted to identify the factors affecting urgency. A p value of $<0.05$ was considered to be statistically significant.

\section{Results}

The mean age of parents was $33.5 \pm 6.4$ years, and $78.4 \%(n=1388)$ of the parents were women and $21.6 \%(n=382)$ were men. According to the time of appeal, $11 \%(n=194)$ of parents visited the ER during office hours. The most common presentations were done in the winter months, $41 \%(n=726)$ (Table 1).

To learn the perception of urgency, the question "In how much time your child should be seen by a physician?" was answered as "In the first $15 \mathrm{~min}^{\prime \prime}$ by $61.1 \%(n=1081)$ of parents (Table 2$)$.
The question "Due to which circumstances would you prefer ER?" was answered as "Illness occurring after office (work) hours" by $42.4 \%(n=1219)$ of parents. A total of $68.9 \%(n=1219)$ of the doctors most often thought that parents brought their children to the ER because of crowded outpatient clinics during the day. One of the most frequent reason because of which parents choose the ER is that "ER is more quick with regard to examination and laboratory procedures and less time consuming with regard to waiting in hospital" (Table 3 and 4).

A total of $72.4 \%(n=1281)$ of participants stated that they had not consulted anybody regarding their child's illness. There was not a doctor who always follows $71.4 \%(n=1263)$ of parents' children in routine. A total of $57.5 \%(n=1017)$ of parents brought their children

Table 1. Sociodemographic characteristics of parents

\begin{tabular}{|c|c|c|c|}
\hline Demographic parameters & & $\mathbf{n}$ & $\%$ \\
\hline \multirow[t]{2}{*}{ Gender } & Female & 1388 & 78.4 \\
\hline & Male & 382 & 21.6 \\
\hline \multirow[t]{2}{*}{ Time of application to ER } & Worktime & 194 & 11 \\
\hline & Except worktime & 1576 & 89 \\
\hline \multirow[t]{4}{*}{ Seasons } & Winter & 726 & 41 \\
\hline & Spring & 405 & 22.9 \\
\hline & Summer & 234 & 13.2 \\
\hline & Autumn & 405 & 22.9 \\
\hline \multirow[t]{4}{*}{ Relationship } & Mother-Father & 1651 & 93.3 \\
\hline & $\begin{array}{l}\text { Grandfather- } \\
\text { Grandmother }\end{array}$ & 50 & 2.8 \\
\hline & Relative & 61 & 3.4 \\
\hline & Babysitter & 8 & 0.5 \\
\hline \multirow[t]{4}{*}{ Education level } & Primary School & 231 & 13.1 \\
\hline & Secondary School & 332 & 18.1 \\
\hline & High School & 709 & 40.1 \\
\hline & College & 498 & 28.1 \\
\hline \multirow[t]{5}{*}{ Age groups } & $19-29$ & 459 & 25.9 \\
\hline & $30-39$ & 1060 & 59.9 \\
\hline & $40-49$ & 202 & 11.4 \\
\hline & $50-59$ & 46 & 2.6 \\
\hline & $60-69$ & 3 & 0.2 \\
\hline
\end{tabular}

Table 2. Parental and doctors' perception of urgency

\begin{tabular}{|c|c|c|c|c|c|}
\hline \multirow{2}{*}{$\begin{array}{l}\text { In how much time } \\
\text { your child should be } \\
\text { seen by a physician? }\end{array}$} & \multicolumn{2}{|c|}{ Participants } & \multicolumn{2}{|c|}{ Doctors } & \multirow[b]{2}{*}{$\mathbf{p}$} \\
\hline & $\mathbf{n}$ & $\%$ & $\mathbf{n}$ & $\%$ & \\
\hline First $15 \mathrm{~min}$ & 1081 & 61.1 & 76 & 4.3 & \multirow{6}{*}{$<0.001$} \\
\hline $15-60 \mathrm{~min}$ & 494 & 27.9 & 12 & 0.7 & \\
\hline $1-2 \mathrm{~h}$ & 94 & 4.1 & 261 & 14.7 & \\
\hline $2-12 \mathrm{~h}$ & 47 & 2.7 & 135 & 7.6 & \\
\hline $12-24 \mathrm{~h}$ & 22 & 1.2 & 149 & 8.4 & \\
\hline Can wait until the day after & 32 & 3 & 1137 & 64.2 & \\
\hline
\end{tabular}


to the ER without any intervention; $14.1 \%(n=249)$ of the parents visited the ER for the first time in the past year because of their child's illness. A total of $30.2 \%(n=534)$ of the parents thought that a personal physician's clinic is the best location for the care of their children's illness.

According to the CDC criteria, $19.7 \%(n=349)$ of the children were in the group of "Urgent." Having a doctor who follows the children's health and a physician and/or a medical staff for consultation leads to a significant increase in terms of real urgencies $(p<0.001)$. Making an intervention before bringing the children to the ER is significantly high in the "urgent" group $(p<0.001)$ (Table 5).

There was a significant positive moderate correlation between the seasons and the group that was identified as urgent by the doctors $(r=0.386, p<0.001)$. There was a moderate and positive correlation between the urgency situation and the number of regular health checkups of the children $(r=0.347, p<0.001)$. A strong positive correlation was found between the urgency situation and the education level of parents $(r=0.950, p<0.001)$ (Table 6$)$.

Table 3. Comparison of parental reasons for visiting the ER

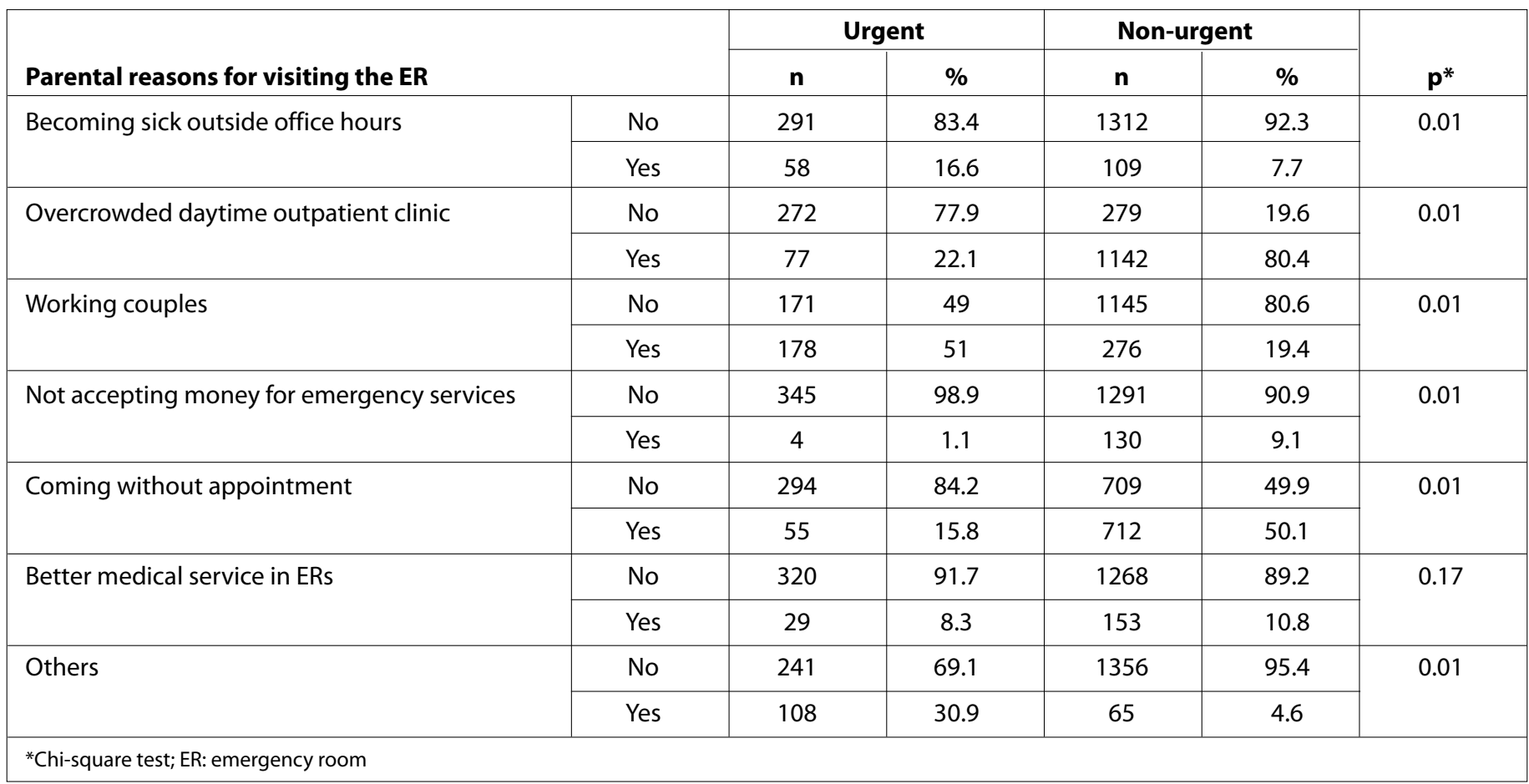

Table 4. Comparison of patients' reasons for visiting the ER

\begin{tabular}{|c|c|c|c|c|c|c|}
\hline & & \multicolumn{2}{|c|}{ Urgent } & \multicolumn{2}{|c|}{ Non urgent } & \multirow[b]{2}{*}{$\mathbf{p}^{*}$} \\
\hline & & $\mathbf{n}$ & $\%$ & $\mathbf{n}$ & $\%$ & \\
\hline \multirow[t]{2}{*}{ Becoming sick outside office hours } & No & 291 & 83.4 & 1312 & 92.3 & \multirow[t]{2}{*}{0.01} \\
\hline & Yes & 58 & 16.6 & 109 & 7.7 & \\
\hline \multirow[t]{2}{*}{ Overcrowded daytime outpatient clinic } & No & 272 & 77.9 & 279 & 19.6 & \multirow[t]{2}{*}{0.01} \\
\hline & Yes & 77 & 22.1 & 1142 & 80.4 & \\
\hline \multirow[t]{2}{*}{ Working couples } & No & 171 & 49 & 1145 & 80.6 & \multirow[t]{2}{*}{0.01} \\
\hline & Yes & 178 & 51 & 276 & 19.4 & \\
\hline \multirow[t]{2}{*}{ Not accepting money for emergency services } & No & 345 & 98.9 & 1291 & 90.9 & \multirow[t]{2}{*}{0.01} \\
\hline & Yes & 4 & 1.1 & 130 & 9.1 & \\
\hline \multirow[t]{2}{*}{ Coming without appointment } & No & 294 & 84.2 & 709 & 49.9 & \multirow[t]{2}{*}{0.01} \\
\hline & Yes & 55 & 15.8 & 712 & 50.1 & \\
\hline \multirow[t]{2}{*}{ Better medical service in ERs } & No & 320 & 91.7 & 1268 & 89.2 & \multirow[t]{2}{*}{0.17} \\
\hline & Yes & 29 & 8.3 & 153 & 10.8 & \\
\hline \multirow[t]{2}{*}{ Others } & No & 241 & 69.1 & 1356 & 95.4 & \multirow[t]{2}{*}{0.01} \\
\hline & Yes & 108 & 30.9 & 65 & 4.6 & \\
\hline
\end{tabular}


Table 5. Comparison of groups in terms of having a doctor who controls the child frequently and a doctor and/or a medical stuff to consult and intervention

\begin{tabular}{|c|c|c|c|c|c|}
\hline & & & Non & & \\
\hline & $\mathbf{n}$ & $\%$ & $\mathbf{n}$ & $\%$ & $\mathbf{p}^{*}$ \\
\hline Frequently controllin & & & & & \\
\hline No & 126 & 36.1 & 1137 & 80.0 & 0.001 \\
\hline Yes & 223 & 63.9 & 284 & 20.0 & \\
\hline Did you make an inte & & & & & \\
\hline No & 142 & 40.7 & 875 & 61.6 & 0.001 \\
\hline Yes & 207 & 59.3 & 546 & 38.4 & \\
\hline Consulting a medical & & & & & \\
\hline No & 169 & 48.4 & 1228 & 86.4 & 0.001 \\
\hline Yes & 180 & 51.6 & 193 & 13.6 & \\
\hline Consulting a doctor & & & & & \\
\hline No & 188 & 53.9 & 1283 & 90.3 & 0.001 \\
\hline Yes & 161 & 46.1 & 138 & 9.7 & \\
\hline Number of presentat & & & & & \\
\hline 1 & 80 & 22.9 & 169 & 11.9 & 0.001 \\
\hline 2 & 174 & 49.9 & 239 & 16.8 & \\
\hline 3 & 21 & 6 & 309 & 21.7 & \\
\hline 4 & 11 & 3.2 & 150 & 10.6 & \\
\hline$>5$ & 63 & 18.1 & 554 & 39 & \\
\hline What is the best loca & & & & & \\
\hline ER & 94 & 26.9 & 654 & 46 & 0.001 \\
\hline District clinic on duty & 9 & 2.6 & 63 & 4.4 & \\
\hline Private doctor & 169 & 48.4 & 365 & 25.7 & \\
\hline Private hospital & 77 & 22.1 & 339 & 23.9 & \\
\hline
\end{tabular}

\section{Discussion}

Pediatric emergency medical service is an important part of emergency services. At present, health care managements have been making great efforts to provide effective pediatric emergency services. However, the results are not as successful as expected. One of the most important reasons for this is the false perception of urgency as well as inappropriate presentations to the ER (2-7). On one hand, non-emergency patients prevent real emergency patients from being treated; on the other hand, the workload reduces the quality of service in the ER (3-6).

There are many reasons for the parents to visit emergency services on their own instead of primary health care units. The reasons are as follows: parents' wrong perceptions of urgency, receiving health care services instantly and quickly, benefiting from laboratory facilities rapidly, and belief that the ERs are better equipped and are efficient health care units. However, on the basis of the above mentioned reasons, it is undeniable that parents' education is lacking (3-6).

In our study, we did not find a significant difference in terms of gender between the urgent and non-urgent patients. Gill et al. (12) found that presentations to the pediatric ER are on an equal level in terms of gender. This result was similar to that of our study.
In the study by Kalidindi et al. (13), it was reported that when the educational levels of parents who were admitted to the ER increases, the reality of the urgency increases. Baker (14) had reached similar conclusions with regard to the educational status and emergency cases. In our study, most of the presentations to the ER were by parents who were high school graduates. In addition, parents of children who were really considered to be emergency cases were more likely to be in the group of college degree. This status shows that when the education level increases, presentations to the ER are made more accurately.

Burnett and Grover (15) indicated in their study that regular health check-ups on children would decrease the number of applicants to the ER. In our study, only $28.6 \%$ of parents went to a physician for checkup. The number of urgency cases of children, who are continuously monitored by a physician, was higher as expected. This case is notable to demonstrate the importance of regular health check-ups. Primary health care units has an important place in terms of easy accessibility and for providing ongoing maintenance services $(16,17)$. "The Goalkeeper" family physicians recognize, diagnose, and refer the patients; by diagnosing the diseases at an early stage, they reduce the rate of unnecessary presentations to the $\operatorname{ER}(16,17)$. 
Table 6. Statistical correlation in the perception of urgency

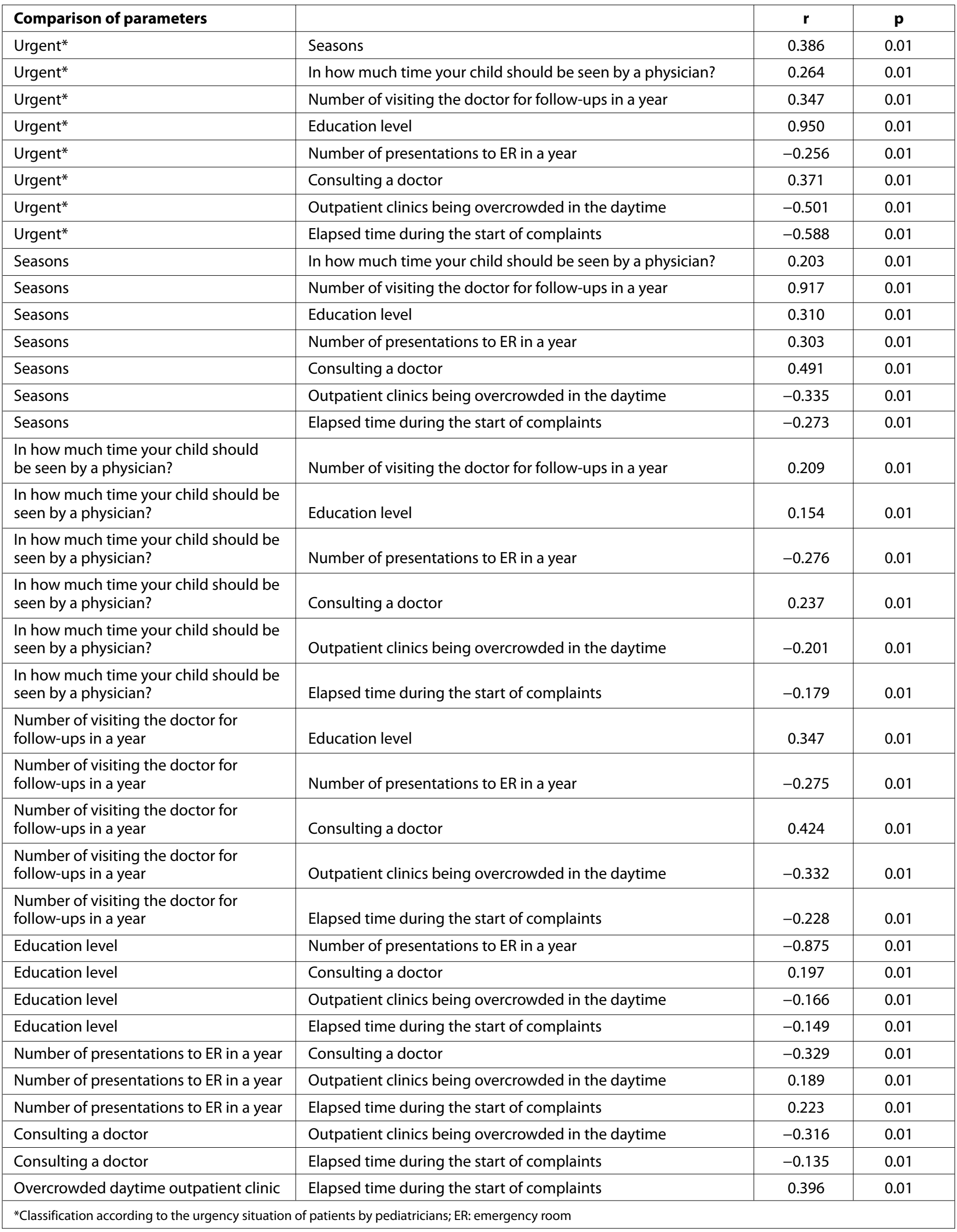


In the study by Yurdakok (18), it was seen that, child health monitoring (follow-up) decreases the child mortality and ER visits of families as well as increases the prevention of diseases and morbidity. In our study, having a doctor who monitors the child frequently and a doctor and/or a medical stuff for consultation result in a statistical significant increase in terms of real urgencies $(p<0.001)$. We suggest that, if the number of children under regular monitoring increases, the visits to the ER for the correct reason will also increase.

Ayvaz et al. (19), in a study regarding examination of the characteristics of pediatric patients brought to the ER, showed that the parents consult people around them before coming to the ER. In our study, we detected that $72.4 \%(n=1281)$ of parents did not consult anybody before coming to the ER.

In our study, $42.5 \%$ of parents stated that they had a medical attention before coming to the ER. These medical attentions are as follows: using antipyretics, shower mind, and consulting a health personnel. Performing simple medical interventions before admission to the ER can provide significant benefits. Well-educated parents try to perform the first intervention on their own and perceived the ER as the second reference point. Thus, for raising the awareness of the families, the most important role is played by the family doctors.

There are different results in the literature about the rate of real urgency of the patients who visited the ER. Civaner et al. (20) found that $53.3 \%$ of the patients who were admitted to the ER of the state hospital were identified as an actual urgency. In the study by Atabek et al. (21), this ratio is $52 \%$. CDC identifies the urgency rate of presentation as $45.2 \%$. However, Gürsoy et al. (22) indicate that among patients presented to the ER, $80.8 \%$ were outpatients; the proportion of patients reported as an actual urgency is $20 \%$. In our study, this ratio was determined to be $19.7 \%$. This difference in rates may be because of differences in urgency assessment criteria.

In the study by Ayvaz et al. (21), the rate of families who came to the ER because the outpatient clinics were crowded was 3.2\%. In our study, $40.6 \%$ of parents stated that outpatient clinic were crowded during the day. According to the literature, this percentage is very high. In the group of urgent patients,' most parents declared that their reason for visiting the ER was because of their work. This difference can be explained because a majority of the parents of our group were working.

Another attraction point that was most commonly mentioned by $25 \%$ of the participants is quick examination and analysis in the ER. When we asked similar questions to doctors who examined the patients, they stated that the most common reason of presentation to the ER is the overcrowding in outpatient clinics.

\section{Study limitations}

Our study is a single-center study. The education and the sociocultural characteristics of a vast majority of parents who brought their children to our ER are homogenous. The perception regarding the ER visits of parents of low education level could be different. This may influence some of the results in our study. There is no triage system in the pediatric ER that we worked at. This could also increase the workload of the ER. In addition, it could be better if we compare between the number of presentations to the primary care family doctors who monitor the children continuously and the number of presentations to the ER.

\section{Conclusion}

It is seen that, pediatric ERs provide outpatient clinic services rather than emergency service. The reason for this situation is parents' false perception of urgency. This misperception may be eliminated or decreased by increasing parental awareness of this situation, dissem- ination of primary health care system, and configuration of the triage systems in pediatric ERs like other ERs.

Ethics Committee Approval: Ethics committee approval was received for this study from the ethics committee of Gülhane Military Medical Academy.

Informed Consent: Written informed consent was obtained from patient who participated in this study.

Peer-review: Externally peer-reviewed.

Conflict of Interest: No conflict of interest was declared by the authors.

Financial Disclosure: The authors declared that this study has received no financial support.

\section{References}

1. American College of Emergency Physicians. Definition of Emergency Medicine and Emergency Physician. Ann Emerg Med 1986; 15: 1240-1. [CrossRef]

2. Schneider SM, Hamilton GC, Moyer P, Stapczynski JS. Definition of emergency medicine and emergency physician. ACAD Emerg Med 1998; 5: 348-51. [CrossRef]

3. Adaş G, Sarvan F, Küpelioğlu R. Hastanelerde acil ve kaza servislerinin planlanması ve fiziksel organizasyonu. Ulusal Travma ve Acil Cerrahi Derg 1998; 1: 1-6.

4. James SC. Introduction to management: definitions, utilization and workforce Issues. principles and practice of emergency medicine. 4th ed. Lippincott Williams and Wilkins 1999; 1846-52.

5. Prince $M$, Worth C. A study of finappropriate attendances to a paediatric accident and emergency department. J Public Health Med 1992; 14: 177-82.

6. Karaböcüoğlu M, Kartoğlu U, Molzan J, Uğur S, Uzel N, Neyzi O. Analysis of patients admitted to the emergency unit of a university children's hospital in Turkey. Turk J Pediatr 1995; 37: 209-16.

7. American College of Emergency Physicians Board of Directors. Bona fide emergency In Policy Summaries. ACEP 1994: 7-8.

8. Glanz K, Rimer BK, Lewis FM. Health Behavior and Health Education: Theory, Research, and Practice 3rd edition. John Wiley and Sons Chichester, 2002.

9. Afilalo M, Guttman A, Colacone A, Dankoff J, Tselios C, Beaudet M, et al. Emergency department use and misuse. J Emerg Med 1995; 13: 259-64. [CrossRef]

10. Shiber JR, Longley MB, Brewer KL. Hyper-use of the ED. Am J Emerg Med 2009; 27: 588-94. [CrossRef]

11. Moskop JC, Sklar DP, Geiderman JM, Schears RM, Bookman KJ. Emergency department crowding, concept, causes, and moral consequences. Ann Emerg Med 2009; 53: 605-11. [CrossRef]

12. Gill, JM, Reese CL, Diamond JJ. Disagreement among health care professionals about the urgent care needs of emergency department patients. Ann of Emergency Med 1996; 28: 474-9. [CrossRef]

13. Kalidindi S, Mahajan P, Thomas R, Sethuraman U. Parental perception of urgency of illness. Pediatr Emerg Care 2010; 26: 549-53. [CrossRef]

14. Baker D, Ruddy RM, Fleisher GR, Ludwig S. Textbook of pediatric emergency medicine. Lippincott Williams and Wilkins 2000; 1067-86.

15. Burnett MG, Grover SA. Use of the emergency department for nonurgent care during regular business hours. CMAJ 1996; 154: 1345-51.

16. Watt WD. The family physician: gatekeeper to the health-care system. Can Fam Physician 1987; 33: 1101-4.

17. Stein HF. Family medicine's identity: being generalists in a specialist culture. Ann Fam Med 2006; 4: 455-9. [CrossRef]

18. Yurdakok K. Sağlam çocukların izlemi. Katkı Ped Derg 1999; 20: 95-106.

19. Ayaz A. Trabzon Sürmene Devlet Hastanesi Acil polikliniğine başvuran çocuk hastaların özellikleri. CÜTıp Fak Derg 2007; 29: 156-62.

20. Civaner M. Bir devlet hastanesinin acil servisine başvuran hastaların analizi. Sağ ve Toplum Derg 1999; 9: 3-7.

21. Atabek ME, Oran B, Çoban H, Erkul İ. Çocuk acile başvuran hastaların özellikleri. Selçuk Üniv Tıp Fak Derg 1999; 15: 89-92.

22. Gürsoy ŞT, Çiçeklioğlu $M$, Türk $M$, Sözbilen M. E.ÜT.F Acil servisine bir yı içinde başvuran hastaların sosyodemografik özelliklerinin ve başvuru zamanlarının değerlendirilmesi. Ege Tıp Derg 1999; 38: 109-12. 